12. Nikitenko P., Bulavko V. Formirovanie transportno-logisticheskoy sistemy Respubliki Belarus. Minsk: Litres, 2017. 349 p.

13. Ermakov I., Petukhov D. Postanovka problemy razvitiya natsional'noy logisticheskoy sistemy // Logistika. 2014. Vol. 11. P. 56-59.

14. Ivut R. B., Zinevich A. S., Skorikov V. A. Theoretic and methodologic basics of development of the national logistics system in the Republic of Belarus // Science \& Technique. 2016. Vol. 15 No. 6. P. 504-510. doi:10.21122/2227-1031-2016-15-6-504-510

15. Alkema V. H. Systema ekonomichnoi bezpeky lohistychnykh utvoren: monograph. Kyiv: Unyversytet ekonomiky ta prava «Krok», 2011. 378 p.

16. Korniietskyi O. V. Teoretychni zasady rozvytku rehionalnykh ta mizhrehionalnykh transportno-lohistychnykh system // Biznesnavihator. 2015. Vol. 2 (37). P. 91-97.

17. Kleyner G. B. Sistemnaya ekonomika kak platforma razvitiya sovremennoy ekonomicheskoy teorii // Voprosy ekonomiki. 2013. Vol. 6. P. 4-28.

18. Kleyner G. B. Gosudarstvo - region - otrasl' - predpriyatie: karkas sistemnoy ustoychivosti ekonomiki Rossii. Chast' 1 // Ekonomika regiona. 2015. Vol. 2. P. 50-58.

19. Kravchenko M. O. Formalizatsiia kontseptsii ekonomichnoi stiikosti pidpryiemstva z pozytsii systemno-strukturnoi ekonomichnoi teorii // Ekonomika ta derzhava. 2015. Vol. 12. P. 31-34.

\section{РАЗРАБОТКА ТЕОРЕТИЧЕСКИХ ОСНОВ ФОРМИРОВАНИЯ НАЦИОНАЛЬНОЙ ЛОГИСТИЧЕСКОЙ СИСТЕМЫ}

Рассмотрено многоуровневую таксономию формирования национальной логистической системы и особенности логистического управления на микро-, мезо- и макроуровнях системы хозяйствования. Определено макроэкономическую средовую структуру и показатели эффективности логистической деятельности по уровням управления. Предложено драйверы и систему регулирующих факторов и рычагов государственного воздействия на развитие национальной логистической системы.

ключевые слова: логистические потоки, логистическое управление, национальная логистическая система, государственное регулирование логистической деятельности

Grygorak Mariya, PhD, Associate Professor, Head of the Department of Logistics, National Aviation University, Kyiv, Ukraine, e-mail: m_grigorak@ukr.net, ORCID: https://orcid.org/0000-00025023-8602

\section{Horbonos F., Pavlenchyk $\mathbf{N}$., Pavlenchyk A., Skrynkovskyy $R$.}

\title{
STUDY OF COOPERATION IN AGRIBUSINESS AS A SOCIO-ECONOMIC PHENOMENON
}

Проведено аналіз наукових методологічних підходів до розуміння сутності кооперащіі. Подається новий конщептуальний підхід до розуміння кооперащії, який визначає, що за змістом кооперація є економічним явищем, а за організаційною формою - кооператив. Обгрунтовано формування $і$ функціонування кооперативу на основі прояву внутрішніх $i$ зовнішніх відносини, носіями і регуляторами яких є кооперативні принципи.

Ключові слова: кооперація в агробізнесі, виробничі відносини, кооперативні принщипи, внутрішні і зовнішні відносини.

\section{Introduction}

Agribusiness covers various spheres and types of activity, operates on a corporate basis with reference to production. This concept should be viewed as the cooperation of a number of industries - agricultural, procurement, sales, processing enterprises, banks and other structures related to the production and sale of technological processes. The peculiarity of this concept is that the final product of one industry is the source for the other and forms the agrarian sector of the economy. Agribusiness is an open, holistic system that consists of structurally-structured elements that are organically interrelated, the functioning of each of which interacts the development of the entire system. Components of agribusiness are: enterprises-producers of means of production, agricultural products and their processing, procuring, storage, sales, agrarian service enterprises, infrastructure enterprises and enterprises of other sectors of the economy.

Before the agrarian sector, which is the main link of agribusiness and the most important component of the Ukrainian economy, there is an urgent task to ensure the country's food security, the welfare of the population, and its political and economic independence. One of the direc- tions of this task is development of cooperative relations. Cooperation as an organizational form of management and the system of economic relations contributes to the formation of the ideology of protection of rural commodity producers, their involvement in integration processes, which allows taking advantage of large-scale production without additional capital investments. This is an effective, weighty tool in a market economy that ensures the solution of the problem of pricing for agricultural products and determines the organized opposition of the monopoly in overstating the prices of resources for agricultural commodity producer

\section{The object of research and its technological audit}

The object of research are the processes of development of cooperative relationships in agribusiness, which form the basis of an economic phenomenon, the essence of which is cooperation, as well as the formation and improvement of its organizational and legal forms. Agribusiness is such sphere of entrepreneurial activity, the effective development of which is capable, to a decisive degree, of ensuring the welfare of the population, creating conditions for the 
successful development of other industries. This will contribute to raising the level of economic, and therefore political, security of Ukraine. One of the directions for transforming this possibility into reality can be the development of cooperative relations. Cooperative enterprises based on private property tend to provide freedom of economic choice and full responsibility for the final results of their activities, while creating conditions for increasing the motivation level of members of the cooperative for high-performance work. Such enterprises rely on their own financial resources, have a management system built on democratic principles.

For today, the existence of cooperative formations is justified by centuries of practice, and its objectivity is beyond doubt. Virtually all farmers in Germany, Austria, the United Kingdom, Sweden, the United States and Canada are members of agricultural cooperatives. In the USA, $75 \%$ of the agribusiness sector is covered by cooperative ties. In the market of this country $80 \%$ of milk, $60 \%$ of grain and cotton, $35 \%$ of meat is produced by cooperatives. The whole world knows the American agricultural cooperative Land O'Lakes. This dairy cooperative, which covers almost the entire northern part of the United States, unites more than 700 cooperative members, and its name is synonymous with the highest quality of dairy products [1].

\section{The aim and objectives of research}

The aim of research is development and substantiation of the methodological foundations of the interpretation of «cooperation» concept and the identification of a cooperative organization and the solution of an important national economic problem - the revival and development of cooperation in the agrarian business as the basis for increasing its effectiveness.

To achieve this aim, it is necessary to solve the following tasks:

1. To designate the functional structure of agribusiness.

2. To denote the conditions favorable for the effective development of cooperation, which manifest themselves in the actions of specific factors.

3. To identify the essence and justify the notion of «cooperation» and «cooperative», adequate to their actual content.

4. To identify the essence of the regulation mechanism of relationships in the cooperative.

\section{Research of existing solutions of the problem}

The research of problems of cooperation is carried out by world-famous scientists who adhered to different theoretical foundations and had different views on the future structure of the country. In particular, in [2-4], cooperation is considered as an industrial necessity. The authors saw in cooperation primarily a method of economic strengthening of small-scale production, as purely economic necessity, as a means of raising the people's well-being.

The original thought was a famous figure, a theoretician of cooperation, who wrote: «The mission of cooperation is to make people morally and economically». That is, cooperation, as a new social phenomenon, from the very first steps of its existence was oriented not only to raising the material well-being of its members, but also to the formation of spiritual well-being.
Curious views on the objectives of cooperation were the views of the leaders of the Imperial Union, which arose in Germany in 1877, who considered the moral and spiritual goals of agricultural cooperation as related to economic goals. The resolution adopted by them noted that «the moral and economic tasks of cooperative institutions are equally important; the advantage of one of them at the expense of the other is false and goes to the detriment of cooperative societies» [5]. In other words, agricultural cooperation can't develop successfully, while other aspects of public life are in decline.

A peculiar approach to understanding cooperation is seen in the works [6-8]. The authors of these works consider the essence of cooperation through the prism of cooperative principles, which reflect the specific goals and uniqueness of cooperation as a kind of business.

Ukraine has rich own experience in researching the theory and methodology of agricultural cooperation. The world-famous Ukrainian cooperative scientists have proved that this form of economic relations corresponds to the conditions of Ukraine and the mentality of the Ukrainian peasantry [9-11]. In particular, in [11], cooperation is seen as a means of creating a new society, the formation of the Ukrainian nation, the education of a free, initiative, capable of productive public service work.

However, despite the scientific and practical value, none of the works of these and other scientists can claim to be final in solving a number of important problems related to the investigated phenomenon. Especially in terms of a conceptual approach to defining the essence, meaning and basic concepts of cooperation.

\section{Methods of research}

The research is carried out using the dialectical method of cognition and a systematic approach to the study of economic processes and phenomena in their unity and interrelationship. Economic phenomena in this study are not considered in isolation and in isolation from specific historical circumstances, but comprehensively in the process of the withering away of old and the emergence of new forms, in interconnection and development. This approach is carried out in the course of analyzing the experience of studying relevant developments of scientists on the development of cooperative relations. The problems of development of cooperation and its effectiveness in agribusiness are investigated taking into account specific economic conditions and the real state of the economic, political and social situation in the country and in the organic unity of its historical aspects to the logic of the origin of this phenomenon.

\section{Research results}

The agribusiness system in the agrarian sector of the economy is a multifaceted form of entrepreneurial activity, which is an open, holistic set of organically interconnected structurally-creating elements, the functioning of each of which mutually develops their harmonious development [12]. Agribusiness includes a large number of branches of the economy that are inextricably linked with the production and sale of agricultural products and ensure the continuity of the technological process, when the final product of one industry is the initial means of production for the second (Fig. 1). 


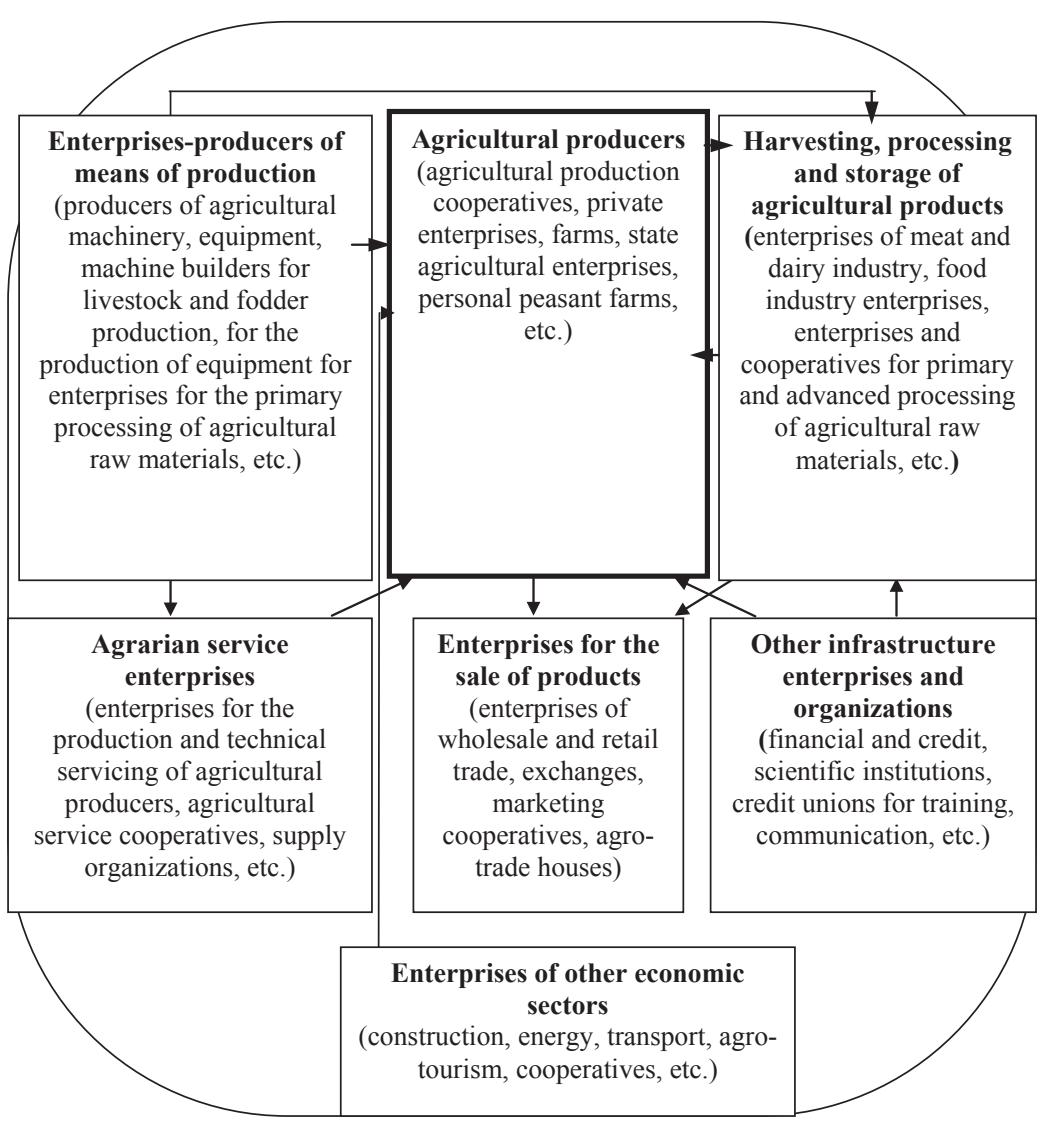

Fig. 1. Functional structure and interrelations of agribusiness
- repair, maintenance of machinery and performance of a certain type of work, which require special equipment;

- organization of nurseries, research and demonstration fields, farms and entire farms;

- organization of a cheap loan for production purposes;

- provision of consulting and information services;

- scientific support.

Obtaining such services in another way is often or physically impossible, or economically impractical.

Therefore, the realization of this economic goal requires the unified physical, material, financial and human resources within the cooperatives. The cooperation widely uses small forms of management, actively supports small and medium-sized enterprises, thus occupying a place in the economic system.

In other words, the economic importance of cooperation lies in meeting the needs of producers in providing means of production, processing and marketing of products.

And also in the provision of other types of services that are necessary for agricultural activities and on this basis - in raising the standard of living of all participants in cooperation.

Significant impact on the functioning of the agribusiness system is not only internal, but also external factors in relation to its environment. All this in itself expands and deepens the influence and significance of factors, repeatedly increases the degree of influence on the development of the internal and external environment, growing uncertainty and various risks. Risk is an indispensable attribute of a market economy and acts as a kind of effort by a subject to act aimed at obtaining a high result [13]. This shows its positive property. Moreover, in conditions of rational use of various methods and means, it is possible to manage it and direct it towards the set goal in the economic sense, which in the final result will ensure the development of production and the enterprise as a whole.

In the concept of further development and raising the efficiency of agricultural production, cooperation takes a special place. Cooperation, as a form of collaboration, permeates all the structures of the economy of each country, regardless of the nature of its socio-economic formation. The cooperation, which arose out of the interests and needs of producers, large and small, received a large-scale development, transformed into a wide network of various cooperative forms and associations of developed countries.

The main task of cooperation in agribusiness is defined as assistance to agricultural producers in the development of their economy and increasing efficiency. This task is detailed in the following possible areas:

- purchase of agricultural machinery and implements, mineral fertilizers, seeds and other means of production;

- processing, marketing and products produced for sale as a commodity; methodological foundations has already been developed in world theory or practice. To develop a single methodological approach to understanding the notion of «cooperation», it is necessary to unite the efforts of scientists to develop theoretical foundations. This process will occur during outlining new thoughts. It is necessary to develop the methodological foundations of the problem, the solution of which can ensure the formation and implementation of cooperative policies, both at the present stage and in the future.

The «cooperation» concept because of its amorphousness causes many contradictory opinions, controversial approaches and views. The word «cooperation» is applied to various types of concepts and sometimes not adequate in its content. In many works such concepts as «cooperation», «cooperative idea», «cooperative movement», «cooperative activity», «cooperatives» and others [6, 11, 14-16] are closely intertwined, and sometimes substitute for each other. It is for this reason that there is an economically vague interpretation of «cooperation» concept in scientific works, its imperfect interpretation in the original sources.

In the economic literature, various conceptual approaches to the understanding of «cooperation» are considered, which basically treat cooperation as an organizational structure or as a process of uniting efforts and resources and identify it with the existence of a set of similar cooperatives (Fig. 2).

In many cases, the definition of «cooperation» is based on homogeneity and uniformity or identification with its
It can't be assumed that a sufficient understanding of the true nature of cooperation, its logical, theoretical, a certain time interval using the experience gained and 
organizational structure - the cooperative. It is precisely that the conceptual approach to the interpretation of «cooperation» concept is built through its organizational structure and appears to us methodologically mistaken. In this approach, only the organizational foundations of cooperation are available and the nature of the conditions for its development is not reproduced, cooperation is not characterized as cooperation from the point of view of production relations. Therefore, consider cooperation as a form of socialization of labor, that is, as a voluntary association of people for joint economic activities. And in this regard, to divide it into production, consumer, credit, housing construction, etc., on the basis of the existence of the same type of cooperatives, as laid down in the normative legal acts of Ukraine [17], is inadequate.

It is possible to consider cooperation as an ideology and economic structure, as well as a form of organization of labor and the form of the enterprise. Then two directions of the theoretical approach are traced. The first is the cooperative movement as a specific ideology for the protection of commodity producers, the creation of a society of social justice and the second - from the standpoint of the economic and organizational and production conditions for its formation, functioning and improvement [12].

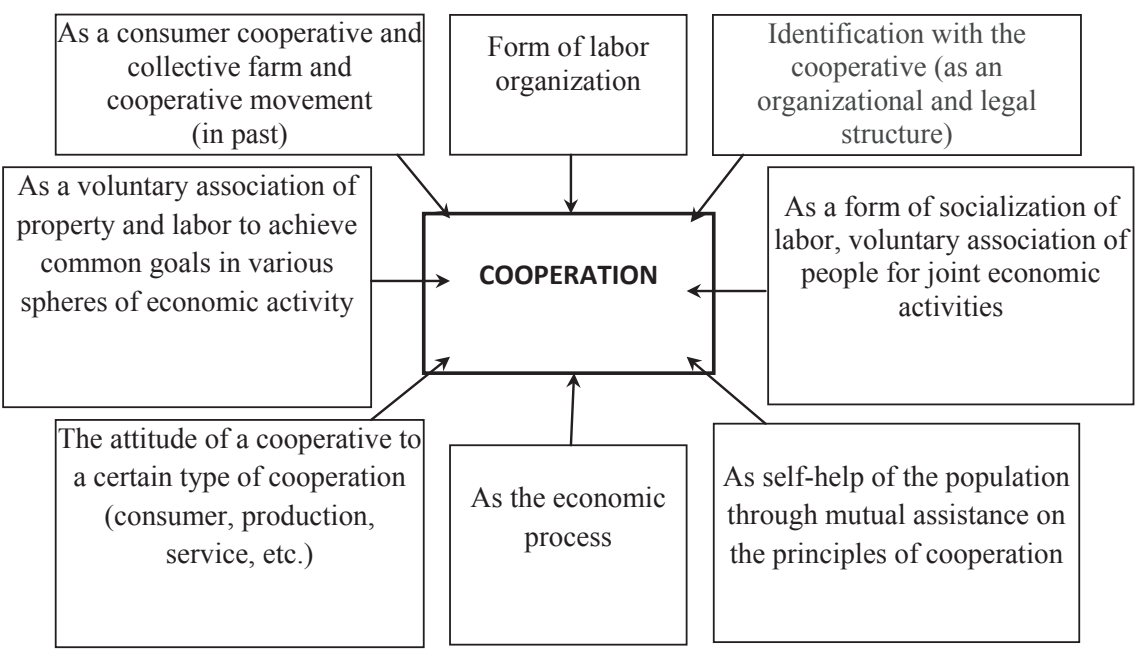

Fig. 2. Conceptual approach to the cooperation definition

Investigating the essence of «cooperation» term, it is unacceptable to identify it with the notion of «labor cooperation», since it logically leads to the fact that they should exist within the framework of one enterprise on the basis of horizontal concentration of production. This was introduced into the practice of collectivization in agriculture. It is irrational to regard cooperation as a process of combining labor, material, intellectual and other resources to work together and achieve a certain goal. This applies to such concepts as «labor cooperation», «cooperation», «inter-farm cooperation», etc.

When combining labor, material and other resources, a formal, purely technical operation is carried out. The concept of «labor cooperation» or «inter-farm cooperation» is based on cooperation, which provides for a number of economic relations and phenomena caused by natural phenomena, technology, political, legal, economic and other factors. These factors can positively or negatively affect their development. Therefore, treating cooperation as a process, let alone an economic one, is not entirely correct, since the process is a successive change of state, a close connection of the stages of development that occur one after another and provide a single continuous movement.

In agricultural production, each operation of the technological process is tangential and has a significant impact on the final result, so it is desirable that all work and operations are performed in a quality and within the agreed time. However, the production process is complicated by natural and economic factors, such as the lack of a permanent place of activity of workers, their narrow specialization, seasonal or insignificant use of separate equipment, the large volume of transportation of materials, raw materials and products, its storage and the like. In addition, agrarian producers in their activities have to involve the main factors of production, raw materials and non-agricultural materials and, turning them into products, again transfer them to the external environment. Consequently, the final results of rural producers depend not only directly on the level of development of a functioning agricultural enterprise and the inspired work of its people, but also on the industries and enterprises of the external environment that serve them. It is difficult for real commodity producers to perform by their own efforts not only simple work of the technological process of production of a particular type of product, but also it is necessary to solve such problems as transportation and storage of products, its implementation. The commercial intermediary structures try to take over the function of selling products, which arose on the basis of former infrastructure enterprises, related to agricultural production. But intermediaries pursue one goal - to obtain as much profit as possible from rural commodity producers. Under such circumstances, agricultural producers can't function effectively. It is necessary to create new structures for the harmonious interaction of all agribusiness partners on the basis of cooperation.

To give a full interpretation and reveal the essence of «cooperation» term, it is necessary to consider the content and form of this concept. Linking the latter only with the organizational structure of cooperation is not enough. A cooperative can only be operative if production relations arise and are formed, both in the business entity itself and from the outside that meet the needs of production, are implemented and developed purposefully, both horizontally and vertically. Cooperatives can cooperate with others, depending on their needs, goals and achievement of certain economic and social goals. The dominant here is the unification of efforts: some - in production activities, others - in the provision of services and the release of key production workers from their uncharacteristic functions.

To cooperate, it is necessary to enter into production relations on certain principles and conditions. Due to the needs of production there is a whole series, or rather a system of economic relations that are mutated and self-replicating. A change in the form of production 
manifestation or economic relations is nothing but a phenomenon. Industrial relations, which are formed on the principles of cooperation, are inherently cooperative, and their ultimate goal is the production of a product ready for consumption or services to meet needs. And it is not necessary that the partners are cooperatives. These can be enterprises of any type: cooperatives, societies and other economic structures. The cooperation as a phenomenon is more dynamic in comparison with its understanding as a form.

Let's believe that the conceptual approach to the study of cooperation must be based on understanding it as a phenomenon, for the development of which, as for the development of any phenomenon (chemical, biological, physical, economic, natural, etc.), appropriate conditions are necessary [18]. The influence of these conditions on the level of development of cooperative relations is manifested in the actions of specific factors that can be grouped by value.Production: provision with means, materials and resources; need and demand for products; quantity and quality of products; implementation period; conditions of production and sales of products.

Organizational-base: motivation, base and procedure for creating a cooperative; method of attracting seed capital; advisory, information and scientific and methodological support for cooperation development.

Exciting-legal: legislative and legal framework for development of cooperation; availability of legal guarantees and protection of property; stability of the country's economy; taxation system and tax benefits; availability by type of activity; financial and credit services.

Stabilizing: availability and level of infrastructure development; degree of equality of opportunities for development of various organizational forms; public opinion on the cooperation development; the attitude of the state towards this phenomenon; equality of opportunity in competition with state-owned enterprises.

Without rejecting in principle the diversity of opportunities and needs, it would be most appropriate to consider cooperation from the standpoint of economic theory as a socioeconomic category. The essence of such cooperation is the expression of relations between people in the process of their cooperation for the realization of economic interests and achievement of a mutually beneficial goal on the basis of joint use of resources, due to a fair distribution of the obtained synergetic effect.

The form of cooperation and its organizational structure is the cooperative, which is created and operates on the basis of cooperative principles, which are carriers and regulators of internal and external relations. Cooperative enterprises provide freedom of economic choice and full responsibility for the final results of their activities. They are based on their own financial resources and have a management system built on democratic principles.

In the scientific and economic literature, there are various approaches to understanding the concept of «cooperative», which indicates the lack of unity in cooperative scientists regarding a conceptual approach to the interpretation of the cooperative organization and a clear recognition of the nature of this concept. Sufficiently widespread use has been interpreted, in which the organizational structure, formed on the basis of voluntary association of people with a specific purpose, appears. At the same time, it reflects the processes associated with economic, social and legal characteristics and properties in terms of the place, role, value and task of the cooperative. As a result, the definitions become detailed and overloaded, while others, on the contrary, treat the essence of the cooperative concept too much.

The definitions found in scientific sources have certain differences in the wording, but the practical value of the cooperative, which largely corresponds to the interests of its members, is also predominant, are owners and employees of this type of enterprise. The dominant in the interpretation is a voluntary association of people or organizations that have common economic interests and cooperate with a view to achieving them. Principles, however, are generally seen as rendering the cooperative a special, excellent character from other enterprises and provide the rules of action necessary to perform the basic cooperative tasks.

In the documents approved by the International Cooperative Alliance, the cooperative is recognized as a selfgoverning association of persons who have voluntarily united to meet their common economic, social and cultural needs and aspirations by creating an enterprise that is jointly owned and democratically controlled by them [18]. In unison, definitions are often found in the economic literature of Ukraine. For example, a cooperative is a voluntary association of people based on democratic principles, has free access and an unlimited number of members, personally participates in the management of its activities ... with the aim of self-help, self-sufficiency and economic self-protection from exploitation by various representatives [19]. In another scientific work a cooperative is an organization created by producers and processors on the basis of voluntary membership for joint production and processing of agricultural products on the basis of combining their property shares [20]. Cooperative as a corporate enterprise created through the voluntary association of material contributions and efforts of commodity producers - owners, the organization of democratic governance and the sharing of risk and income in accordance with participation in the economic activities of this enterprise [21].

In general, the interpretations of many scientists differ in the presentation of the main characteristics of the cooperative development, its organizational traits, properties, role and significance, and are the result of abstract-logical thinking. In order to establish the theoretical and practical essence of the nature of the content and form of the cooperative, it is necessary to methodologically consider the basic components that make up it - internal and external relations, principles that are the starting-point of both its formation and activity and interpretation.

The addition of a number of fundamental principles that play an important and paramount role in the formation and functioning of the enterprise give the cooperative certain characteristics make the definitions meaningful and understandable. All this necessitates discussion about the economic foundations for the creation and functioning of the cooperative and the grounds for defining the concept. In this regard, the efforts of researchers from different countries should be aimed at finding such definition, with the help of which it is possible to identify any cooperative organization and distinguish it from other types of organizational and legal structures. It should be clear, concise and profound in nature. 
The cooperative's activities are carried out on the basis of labor and the use of means of production as a shared corporate property. In form, the cooperative unites commodity producers and is the production or serving link of a single national economic complex. During the functioning of cooperatives, economic phenomena and elements of their structures are constantly changing under the influence of both internal and external circumstances. Each of the cooperatives does not operate in isolation, but in a certain contact with other business entities. These links can be weak, medium and close. Depending on the degree of activity, they can quickly or slowly influence the activities of the enterprise and affect its interests to some extent.

Relations in cooperatives, manifested at the internal and external levels, are inherently very diverse. At the domestic level, they are manifested as social, on the production level - as economic, in public life - as political and the like. They can be divided into individual and reciprocal, permanent and temporary, internal and external, bilateral and multilateral, mandatory and, if necessary, and the like. But the main and decisive, acting in the spheres of economy and functioning of cooperatives are technological, production-economic and social relations.

There is a significant set of internal relations, for example:

- between employees performing sequentially interrelated production operations;

- between different subdivisions of the cooperative regarding the organization of production of final products;

- intraeconomic relations between members of the cooperative regarding the organization of labor and production, the creation of safe conditions and appropriate wages, and the introduction of leases;

- logistical support of work processes, etc.

In addition, as a rule, there are relations of ownership, land, production-economic and social, which are regulated by the Charter, internal regulations, orders, labor payment. Internal relations can be divided into separate groups:

- formation of a cooperative: legal, organizational, selfgovernment;

- production activities: property relations, production relations, organizational and technological relations;

- economic activity: economic relations, credit and financial;

- social activities: social, educational, cultural, spiritual, daily.

Significant impact on the functioning of the cooperative is not only internal, but also external factors. At the external level, relations with other economic entities related to the production and exchange of products, material and technical and credit security, and the like are traced. Relations, both at the internal and external levels, are subordinated to actions and are regulated, mainly, by cooperative principles.

Thus, a cooperative can only be operative if and how the system of production relations arise, both in the business entity itself and from the outside, that meet the needs of production. And also carried out and developed purposefully, both horizontally and vertically. Therefore, the main thing in the interpretation of the concept of a cooperative should be the reflection of relations.

The cooperative as an organizational structure, the country's legislation is guaranteed free choice of economic activity, independence in making decisions on all issues of life, both in the direction of activity, volume and structure of production, and sales of products, and income distribution. The cooperative in its socio-economic nature, works on the basis of self-sufficiency and self-financing. Interference in the economic or other activities of the cooperative on the part of the state and governing bodies, the establishment of any tasks for it, and the resolution of issues within the competence of the cooperative and its bodies is not permitted.

The cooperative, as the primary link in the system of cooperative structures, actively participates in the economic and social development of social production. For the most complete satisfaction of the growing material and spiritual needs of people and in order to solve their tasks, the cooperative can make any decisions, if they do not contradict the current legislation and its Charter. The cooperative is recognized as a legal entity, enjoys the rights and performs the duties related to its activities, has an independent balance. The cooperative is an enterprise of a special organizational and legal form, carrying out economic activities on the principles of entrepreneurship with the aim of generating income and differs from any other commercial structures or societies in that it combines not capital but joint work. In the cooperative labor relations are not separated from property relations, and its main goal is related to the satisfaction of the needs of its members.

In the process of formation and functioning, cooperatives cooperate, unite and integrate. In this case, the activity of individual cooperatives is subordinated organizationally and technologically to a union or association, which, as a rule, is larger in scale and can carry out activities at the local, regional, national and even international level. Regardless of this, the principles of formation and functioning always remain the same that is based on the principles of membership and voluntariness for joint activities in the field of agricultural production.

The desire of cooperatives to unite is a natural phenomenon. In many countries of the world they not only unite in alliances, associations, unions, but also create national federations and leagues of various cooperatives. The expediency of such associations is conditioned by the need for coordination and expansion of co-operatives' cooperation, state support and protection in order to increase the efficiency of their functioning. Primary cooperatives and decide to establish a regional or specialized association.

As a form of organization of production, the cooperative operates on the basis of private property, but each member of the cooperative knows how much capital it owns. In addition, the production cooperative provides an opportunity for a certain social protection of the disabled owners of property and land shares as its associated members, which is not found in other types of formations.

\section{SWOT analysis of research results}

Strengths. The interpretation of cooperation as an economic phenomenon, the essence of which is development of the system of relations between its participants, is justified. For the further successful development of this phenomenon, appropriate economic, legal, political and social conditions are needed, without which it will not develop. The interpretation of the «cooperative» concept as an organizational form of cooperation of the entrepreneurial type is given, it is created and functions on the basis of cooperative 
principles, which are carriers and regulators of internal and external relations.

Weaknesses. The «cooperation» concept through its amorphousness causes many contradictory judgments, controversial approaches and views, especially inherently as an economic phenomenon. Since the analysis of scientific papers and the results of carried out research are subjective, this provides for the possibility of further discussions.

Opportunities. In market conditions, it is important to streamline the methodological foundations of research, which can ensure the formation and implementation of cooperative policies in agribusiness in order to improve the efficiency of its operation. All this calls for a deep theoretical rethinking of the essence and significance of cooperation, forecasting the immediate prospects for its development, objectively forms the necessity and expediency of creating an appropriate infrastructure for the further successful development of cooperation.

Threats. To introduce research results into the practical activities of agricultural enterprises, the main threat is the instability and dynamism of the political and economic situation in the country, as well as the lack of a regulatory and legal framework for the cooperation development.

\section{Conclusions}

1. The research results show that agribusiness can be viewed in the organizational, sectoral and functional areas. From the structural and organizational point of view, «agribusiness» is the equivalent of the country's agro-industrial complex. In the sectoral plane, the term «agribusiness» is used to refer to sectoral food sub-complexes as a single whole of production, processing and marketing of a certain type of agricultural products and characteristics of how market conditions are undergoing integration processes in a particular field. And, considering the functional activity, agribusiness should be considered in the context of development of entrepreneurship in the agrarian sphere.

It is determined that for cooperation development, as for any other phenomenon, favorable conditions are necessary. First of all:

1) recognition by the state of the democratic nature of production, in which free choice and implementation of any type of economic activity is possible;

2) presence of the legal status of protection of cooperatives and cancellation of any state intervention in their economic activities;

3) recognition and functioning of various forms of ownership;

4) availability of a flexible economic mechanism and preferential tax support;

5) state support of ideology with regard to specific forms of cooperation and wide popularization of its advantages;

6) targeted credit assistance to the state in the formation of cooperatives, a reasonable combination of socioeconomic interests of the state and co-operators.

2. In the course of the research, it is determined that cooperation in its content is an economic phenomenon, the essence of which is economic relations between partners, on their cooperation to achieve a common goal with less unit costs of resources, on the basis of mutual benefit for all participants. This methodological approach to understanding cooperation is important from a practical point of view, since it assumes the creation of an infrastructure, as an indispensable condition for the further successful development of this phenomenon.

It is established that the main thing in the interpretation of the concept of a cooperative should be the reflection of relations and their regulation both in the cooperative itself in its formation and activities, and with the enterprises and organizations that create its external environment. Since the entire set of elements, as well as all facets of the main aspects of the cooperative's economic relations, both internally and externally, are very mobile, they manifest themselves in close interweaving and are in a dynamic state to mutual development. That is why in the treatment of the concept of «cooperative» it is expedient to show the economic nature in the format of relations and the important role played by the principles as their carriers and regulators. The cooperative is a form of cooperation and its organizational structure of an entrepreneurial type, it is created and functions on the basis of cooperative principles that are carriers and regulators of its internal and external relations.

3. It is shown that the totality of the manifestation of the cooperative's relationships for reasons of origin, content and purpose encompasses all stages in the formation and functioning of social production-from decision-making to the completion of the distribution of the obtained results. The essence of the mechanism for regulating these relations is expressed in the direction of observing an equivalent exchange of the results of labor of each member of the cooperative, ensuring mutually beneficial participation in joint activities, and the successful fulfillment of each of these tasks.

\section{References}

1. Land O'Lakes: members. URL: https://www.landolakesinc.com/ Members/Member-News/January-2018/farm-bowl-membersspread-the-word (Last accessed: 28.01.2018).

2. Antsiferov A. N. Ocherk o kooperatsii. Moscow, 1909. 79 p.

3. Kropotkin P. A. Zapiski revolyutsionera. Moscow: Moskovskiy rabochiy, 1988. 544 p.

4. Zassen I. A. Razvitie teorii kooperatsii. Kharkiv: Soyuz, 1920. $21 \mathrm{p}$.

5. Kooperatsiya. Stranitsy istorii. Moscow: Politizdat, 1991. 123 p.

6. Barton, D. G. What is cooperative // Cooperatives in Agriculture. Englewood Cliff: Prentice Hall, 1989. P. 1-20.

7. Barton, D. G. Principles // Cooperatives in Agriculture. Englewood Cliff: Prentice Hall, 1989. P. 21-34.

8. Munkner Hans-H. Co-operative Principles and Co-operative Law. Marburg, 1981. 153 p.

9. Koberskyi K. Etychni ta ekonomichni idei v kooperatsii. Lviv: Kooperatyvna respublika, 1929. 205 p.

10. Martos B. Teoriia kooperatsii. Podiebrady, 1923. 76 p.

11. Tugan-Baranovs'kiy M. I. Sotsial'nye osnovy kooperatsii. Moscow: Tip. t-va I. N. Kushnereva i K., 1916. 521 p.

12. Kooperatsiia v ahrobiznesi / Horbonos F. V. et al. Lviv, 2011. 360 p.

13. Pavlenchyk N. F. Rynok silskohospodarskoi produktsii: teoriia ta praktyka: monograph. Lviv: Liha-Pres, 2015. 312 p.

14. Chayanov A. V. Osnovnye idei i formy organizatsii sel'skokhozyaystvennoy kooperatsii. Moscow: Knigosoyuz, 1927. 338 p.

15. Buzdalov I., Shmelev G. Problemy razvitiya sel'skokhozyaystvennoy kooperatsii v perekhodnykh usloviyakh // Voprosy ekonomiki. 1995. Vol. 1. P. 76-85.

16. Krasheninnikov A. I. Mezhdunarodnyy Kooperativnyy Al'yans. Moscow: Ekonomika, 1980. 230 p.

17. Pro kooperatsiiu: Zakon Ukrainy // Ekonomika APK. 2003. Vol. 9. P. $142-152$.

18. Horbonos F. V. Kooperatsiia: Metodolohichni i metodychni osnovy. Lviv: LDAU, 2003. 264 p.

19. International Co-operative Alliance. URL: https://ica.coop/ en/what-co-operative (Last accessed: 28.11.2017). 
20. Honcharenko V. V. Kredytna kooperatsiia. Forma ekonomichnoi samodopomohy silskoho i miskoho naselennia u sviti ta v Ukraini (teoriia, metodolohiia, praktyka): monograph. Kyiv: Hlobus, 1998. 330 p.

21. Koltunova Yu. I. Sotsial'nye aspekty sel'skokhozyaystvennoy kooperatsii: proceedings // Kooperatsiya i integratsiya v APK na rubezhe XX-XXI vekav. Tyumen', 1998. P. 117-120.

22. Zinovchuk V. V. Orhanizatsiini osnovy silskohospodarskoho kooperatyvu. Kyiv: Lohos, 2001. 380 p.

\section{ИССЛЕДОВАНИЕ КООПЕРАЦИИ В АГРОБИЗНЕСЕ КАК} СОЦИАЛЬНО-ЭКОНОМИЧЕСКОГО ЯВЛЕНИЯ

Проведен анализ методологических подходов к пониманию сущности кооперации. Подается новый концептуальный подход к пониманию кооперации, который определяет, что по содержанию - кооперация является экономическим явлением, а по организационной форме - кооператив. Обоснованно формирование и функционирование кооператива на основе проявления внутренних и внешних отношений, носителями и регуляторами которых кооперативные принципы.

Kлючевые слова: кооперация в агробизнесе, производственные отношения, кооперативные принципы, внутренние и внешние отношения.
Horbonos Fedir, Doctor of Economic Sciences, Professor, Rector, Lviv University of Business and Law,Ukraine, e-mail: fhorbonos@ukr.net, ORCID: http://orcid.org/0000-0002-6563-9847

Pavlenchyk Nataliya, Doctor of Economic Sciences, Associate Professor, Head of the Department of Economics, Management, Hotel and Restaurant Business, Lviv State University of Physical Culture, Ukraine, e-mail: pavlinova75@gmail.com,ORCID: http://orcid.org/ 0000-0001-6164-5644

Pavlenchyk Anatolii, PhD, Associate Professor, Department of Economics, Management, Hotel and Restaurant Business, Lviv State University of Physical Culture, Ukraine, e-mail: pavlenchyk@bigmir.net, ORCID: http://orcid.org/0000-0002-2205-1883

Skrynkovskyy Ruslan, PhD, Associate Professor, Department of Business Economy and Information Technology, Lviv University of Business and Law, Ukraine, e-mail: uan_lviv@ukr.net, ORCID: http://orcid.org/0000-0002-2180-8055

\section{Kolodizieva T., Kotsiuba 0.}

\section{IMPLEMANTATION OF WORLD EXPERIENCE IN CREDIT PROGRAMS OF DEVELOPMENT OF LOGISTICS INFRASTRUCTURE, LOGISTICS SYSTEMS AND TECHNOLOGIES}

Розглянуто основні тенденщї фінансування програм розвитку логістичної інфраструктури провідних країн світу. Проаналізовано міжнародний досвід кредитування програм розвитку об'єктів логістичної інфраструктури на прикладі таких країн, як Філіппіни, США, Індія та Болгарія. Виділено основні організаційні аспекти фінансування логістичної інфраструктури, які доцільно використати в українській практиці і визначати конкурентні переваги розвитку економіки.

Ключові слова: транспортна інфраструктура, логістична система, кредитні програми, фiнансування кредитних програм, смарт-міста.

\section{Introduction}

The modern state of economic system of Ukraine, subsequent development of market partnership and quite difficult consequences of running a business urge national enterprises to:

- search for measures for income increase;

- decrease of total costs;

- reduction of time periods between raw materials buying and selling out the production to the customers, and also to ways of supporting the positive image of the company.

During the recent years it is common for these aims to use creating effective logistics infrastructure. It can much improve enterprise`s indicators and create continuous chain of financial flows management. The results of structural analysis of effective development of world companies show that during the production cycle only $2 \%$ of time is spent for production, other $98 \%$ are connected directly or indirectly with products astir. Generally, expenses on products astir are more than $15 \%$ of the gross national product [1]. It proves significance on the stage of search for mechanisms and sources of effective logistics system funding in the country is the basis of economic growth. The necessity of modernization of transport system in Ukraine and the search for alternative funding ways prove the relevance of the research of implementation of the world experience.

\section{The object of research and its technological audit}

The object of research is the process of logistics infrastructure development programs crediting. 